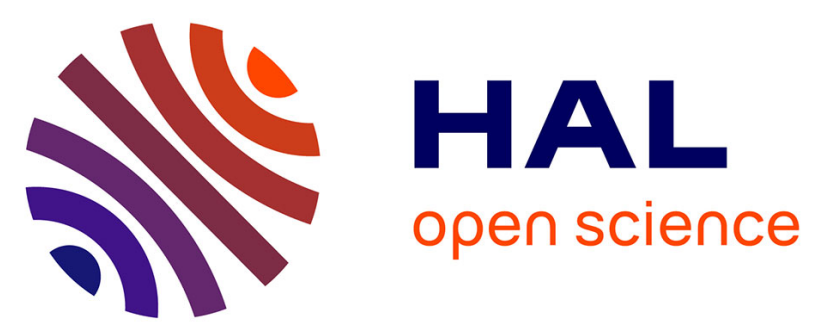

\title{
Pollinators in biofuel agricultural systems: the diversity and performance of bees (Hymenoptera: Apoidea) on Jatropha curcas in Mexico
}

\author{
María Romero, José Quezada-Euán
}

\section{- To cite this version:}

María Romero, José Quezada-Euán. Pollinators in biofuel agricultural systems: the diversity and performance of bees (Hymenoptera: Apoidea) on Jatropha curcas in Mexico. Apidologie, 2013, 44 (4), pp.419-429. 10.1007/s13592-013-0193-x . hal-01201312

\section{HAL Id: hal-01201312 \\ https://hal.science/hal-01201312}

Submitted on 17 Sep 2015

HAL is a multi-disciplinary open access archive for the deposit and dissemination of scientific research documents, whether they are published or not. The documents may come from teaching and research institutions in France or abroad, or from public or private research centers.
L'archive ouverte pluridisciplinaire HAL, est destinée au dépôt et à la diffusion de documents scientifiques de niveau recherche, publiés ou non, émanant des établissements d'enseignement et de recherche français ou étrangers, des laboratoires publics ou privés. 


\title{
Pollinators in biofuel agricultural systems: the diversity and performance of bees (Hymenoptera: Apoidea) on Jatropha curcas in Mexico
}

\author{
María José Romero, José Javier G. QueZADA-EuÁN \\ Departamento de Apicultura - Campus de Ciencias Biológicas y Agropecuarias, Universidad Autónoma de Yucatán, \\ Km. 15.5 carr. Mérida-Xmatkuil, Mérida, Yucatán, México CP 97000
}

Received 17 July 2012 - Revised 27 December 2012 - Accepted 7 January 2013

\begin{abstract}
As with other biofuel crops, information on the effect of insect pollinators and landscape context on the productivity and sustainability of Jatropha curcas is lacking. We studied the effect of pollinator exclusion, self-pollination, cross-pollination and individual visits of the stingless bee Frieseomelitta nigra and the honey bee Apis mellifera on fruit set and weight of fruit and seed of J. curcas. We compared the relative abundance of both bee species on flowers and whether their attributes (ratio of male to female flowers, nectar quantity and quality) affect bee visitation rates. Finally, we sampled various plantations to analyze whether the proportion of forest surrounding a site affects bee abundance and diversity. Significant higher rates of fruit set were obtained from open, cross-pollinated, F. nigra and A. mellifera visited flowers compared to self-pollinated and non-pollinated ones revealing the importance of bees for fruit production. Frieseomelitta nigra and A. mellifera had a similar effect on fruit set and quality, but the former was significantly more abundant on the crop suggesting a better pollinator performance. Male flowers were significantly more visited than female ones by both bee species in spite of their similar amounts of nectar and sugar. The proportion of forest in the surrounding matrix had a positive correlation with bee diversity and abundance on plantations. Our results indicate that preserving patches of forest around the plantations may increase the presence of native bees on Jatropha flowers and ensure sustainable levels of pollination.
\end{abstract}

biodiesel / Jatropha / stingless bee / pollination / physic nut / landscape

\section{INTRODUCTION}

The high prices of petroleum and an interest in reducing world dependence on it have increased the prospects and demand on biofuel (King et al. 2009; Fargione et al. 2010). For this purpose, the plant Jatropha curcas (Mexican physic nut) has gained much attention due to the high oil content of its seeds plus its capacity to grow well in marginal waste lands (King et al. 2009).

Corresponding author: J.J.G. Quezada-Euán, qeuan@uady.mx

Manuscript editor: James Nieh
Jatropha curcas is a deciduous small tree of the Euphorbiaceae family native to Mexico and Central America, but now it is well adapted to tropical and subtropical regions worldwide (Achten et al. 2010). In the last decade, investments and expansion of Jatropha cultivation areas have rapidly increased, in particular in Africa, China and India (Fairless 2007; Ye et al. 2009). There is a large body of information on the breeding system of $J$. curcas originated in these areas (Solomon Raju and Ezradanam 2002; Chang-Wei et al. 2007; Abdelgadir et al. 2009; Kaur et al. 2011; Luo et al. 2011). Given the expanding cultivation of $J$. curcas worldwide, there is an urgent need to optimize its production 
through sustainable management (Abhilash et al. 2011).

Jatropha curcas has been characterized as a monoecious and protandrous plant, i.e. unisexual flowers of both sexes appear on the same plant but male flowers open a few days before the female ones (Chang-Wei et al. 2007; Achten et al. 2010). As flowers are unisexual, pollen needs to be transported from male to female flowers for the production of fruit and seed (Solomon Raju and Ezradanam 2002; Luo et al. 2011; Abdelgadir et al. 2012). Although it has been shown that $J$. curcas can be geitonogamic, insect cross-pollination significantly increases fruit set and seed weight per plant (Chang-Wei et al. 2007; Abdelgadir et al. 2009; Pranesh et al. 2010). Thus, harvestable yields from J. curcas for the biofuel industry and sustainable production could be strongly related to its flower visitors (Caudwell et al. 2003; Abdelgadir et al. 2009; Luo et al. 2011).

Studies from the Old World regard bees as the main pollinating agents of $J$. curcas, in particular species of the highly social genus Apis (Bhattacharya et al. 2005; Atmowidi et al. 2008; Abdelgadir et al. 2009). However, evaluation of the pollinator performance of Apis and other bees, particularly in the region from where $J$. curcas originated, is lacking. The identification and quantification of the pollination service provided by different flower visitors is a prerequisite for the successful establishment of conservation and crop management (Herrera 1987; Free 1993; Jauker et al. 2012). Moreover, pollination efficiency is likely to differ between pollinator species even within a taxon (Hoehn et al. 2008). As $J$. curcas flowers are visited by various insect taxa (Luo et al. 2011), comparative evaluations of their pollinator performance are necessary in order to determine their relative contribution to crop yields. Measuring pollinator performance includes estimations of their abundance and individual efficiency (Freitas and Paxton 1998; Ne'eman et al. 2010).

Another factor seldom considered for sustainability of biofuel production is the landscape context in which crops are grown. Nevertheless, there is supporting evidence of a significant relationship between the proportion of natural habitat with pollinator diversity and abundance and the concomitant rates of pollination on major cash crops (Klein 2009; Ricketts 2004; Brosi et al. 2007; Kremen et al. 2007). Documenting the impact of the landscape could be more relevant in the case of tropical crops pollinated primarily by social bees (as $J$. curcas seems to be), because they seem more susceptible to pollination failure from habitat loss (Ricketts et al. 2008).

Ensuring maximum productivity of biofuel crops is of particular importance in the tropics as there is a risk that their growth can occur at the expense of forests (Fitzherbert et al. 2008; Fargione et al. 2010; Foley et al. 2011). In this study, we surveyed plantations of $J$. curcas in Mexico to document the potential importance that pollinators, specifically bees, may have for the productivity of this crop. Evaluations of the individual visitation activity of honey bees and native stingless bees and their abundance were conducted as well as measures of the production and quality of fruit and seed resulting from their activity. Finally, we calculated a correlation of the proportion of secondary forest in the matrix surrounding the plantations with the number of bee species and specimen abundance in order to provide a measure of the importance of landscapes preservation for biofuel production in Mexico.

\section{MATERIALS AND METHODS}

The two parts of this study were carried out at different times. In the first part, between September 2009 and March 2010, we did controlled pollination experiments in one plantation, also evaluating the pollination efficiency of bees and the effect of flower characteristics on visitation rates. In the second part, in November 2011, we evaluated the diversity of bee species and the effect of the matrix surrounding six plantations.

\subsection{Breeding system}

This study was conducted in a plantation that was composed by ca. 950 plants with an average age of 
5 years. To examine the reproductive system of $J$. curcas, we used methods for controlling pollinator access and applied pollen from different origins to experimental flowers (Dafni et al. 2005).

Fifteen trees were selected for this experiment. Panicles with female flower buds close to anthesis were selected from each tree and covered with cheesecloth bags 2 days before the experiments were conducted. Before bagging, all male flowers and buds closer to the female ones were carefully removed using fine scissors. On the day of the experiments, three female flowers were selected randomly for each of the following treatments per tree. A group of flowers were left unbagged across the experiment to test the effect of open pollination. Another group of flowers was cross-pollinated by rubbing the pistil with the anthers of three mature male flowers collected from different plants. Sets of three different male flowers were used for each female one pollinated in this way. A similar procedure but using male flowers from the same inflorescence were used to test the effect of self-pollination. Self- and crosspollinated flowers were bagged again after treatment to avoid insect visitation. A fourth group of flowers remained bagged during the whole experiment to evaluate the effect of pollinator exclusion. Threads of different colors were tied to the base of experimental flowers depending on the treatment that they received. To avoid the intrusion of insects, such as ants, into the bags, grease and non-toxic glue (Stickem special; Seabright Laboratories) were applied to the basal stem of inflorescences.

We recorded three dependent variables on each treatment flower: fruit set, fruit weight and seed weight. Firstly, fruit set was recorded 6 weeks after the pollination experiments had been conducted; it was calculated as the ratio of fruits/female flowers for each treatment per tree. Secondly, fruit and seed weight were both measured 6 weeks after fruit set was obtained. Weighing was done in an analytical scale with an accuracy of $0.001 \mathrm{~g}$. The individual values of fruit and seed weight per treatment per tree were summed and the results used in further analyses.

To achieve normality before comparison amongst treatments, the data of fruit set were arcsine transformed and those of fruit and seed weight were logtransformed. The transformed data were analyzed under a randomized block design using a GLM procedure with trees as blocks, followed by Tukey multiple comparison tests. The values of fruit and seed weight were compared removing the zero values of the flowers that did not set fruit as this effect was already considered when calculating fruit set.

\subsection{Pollinator performance}

\subsubsection{Insect visitors of flowers}

In a preliminary survey, registration of the taxa and number of insect visitors in the experimental plantation was conducted by walking two rows of 10 contiguous plants on two non-consecutive days. Taxa were identified directly during observations or single specimen collected when identification was impossible in the field. Three minutes of direct observation/ collection per plant were used starting at 1000 hours. The stingless bee F. nigra and the honey bee $A$. mellifera were identified as the most abundant species. It was also possible to observe that male flowers apparently received more visits than female ones, which was studied in further detail.

\subsubsection{Single bee visit experiments for pollination efficiency}

The pollinator efficiency of the honey bee and native bee $F$. nigra were also compared using a similar approach to the evaluation of the breeding system in section 2.1. We used virgin flowers that received single visits from each bee species. Three flowers per tree were pollinated in this way by each bee species and were excluded from subsequent visits by means of a cheesecloth bag. Fruit set, fruit weight and seed weight were obtained for flowers pollinated by the two bee species using the same procedure as for flowers that were hand-manipulated in section 2.1. The results of both bee species were compared between them and with the treatments used to evaluate the breeding system in 2.1 using a randomized block design followed by Tukey multiple comparison tests described in that section.

\subsubsection{Bee visits to male and female flowers}

The relative abundance of $A$. mellifera and $F$. nigra bees in the plantation was recorded on 15 trees. 
One inflorescence was selected on each tree and the number of $A$. mellifera and $F$. nigra bees visiting the flowers were counted during 5 min every $2 \mathrm{~h}$ between 0800 and 1600 hours. The abundance was obtained by summing the number of individuals of each bee on the inflorescences for each of the $5 \mathrm{~h}$ of observation. In order to compare the abundance of each bee species between times, the data were log-transformed and compared using a two-way ANOVA with hour and bee species and their interaction as independent effects followed by Tukey multiple comparison tests. The proportion of visits per bee species was calculated by dividing the numbers of visits by $F$. nigra and A. mellifera recorded per time of observation between the total numbers of visits counted over all plants and sampling times. They were used to plot the relative abundance across the different times of day.

After this initial analysis of bee abundance, we evaluated if male flowers received more visits than female ones using two approaches. Firstly, inflorescences with different ratios of male: female flowers were identified in 15 different trees and the number of bees of each of the two species present in 5 min was counted on each plant in the period between 1000 and 1200 hours on two occasions separated by 1 day. The ratios of male: female flowers per inflorescence were correlated with the number of bees counted on the two occasions using a Spearman's correlation which significance was calculated using a hypothesis test using the Student's t approximation (Zar 1999).

In a following step, we analyzed whether, within bee species, foragers were prone to visit more male than female flowers. For this, the number of times that one female and one male flower on the same inflorescence was visited by $A$. mellifera and $F$. nigra bees was recorded. Twenty pairs of flowers on different trees were evaluated and each pair was observed during $5 \mathrm{~min}$ in three occasions every $2 \mathrm{~h}$ between 0800 and 1200 hours. The mean number of visits by each bee type in the three observations was divided by five to obtain the abundance per min on female and male flowers. The data were log-transformed and comparisons of visits between flower type within each bee species were made using a paired $t$ test.

An additional measure of the relative attractiveness of male and female flowers was obtained by comparing the volume and sugar concentration of the nectar produced in each flower type. For this, two male and two female buds were bagged in 20 different plants using the same procedure as in 2.1 to avoid access of insects. On the day of anthesis, both flowers of each sex were removed from each plant at 1000 hours. The nectar was obtained from each of the four flowers using capillary tubes of $5 \mu$ that were preserved in dry ice and later observed under a microscope to measure the length and calculate the volume of nectar in the tube. Afterwards, the sugar concentration of the nectar was estimated in ${ }^{\circ}$ Brix using a refractometer (Bellingham and Stanley). A single estimate of the volume of nectar and its sugar content was obtained per plant by averaging the measures of both flowers per sex. The comparison between male and female flowers was done by means of a paired $t$ test.

\subsection{Bee diversity and secondary forest surrounding plantations}

To evaluate if the proportion of secondary forest around plantations was important in determining bee diversity and abundance in the crops, we obtained a simple estimate relating both parameters. Six plantations were selected; the nearest distance between them was $10 \mathrm{~km}$. As the total size of the plantations differed, we used a single experimental plot of $30 \times 50 \mathrm{~m}$ in each; the plot was $10 \mathrm{~m}$ in from the edge of the plantation.

Bee diversity and abundance were obtained by direct counting and collecting of specimens with an entomological net when needed. Specimens were directly identified on the flowers or photographed for laboratory identification after which they were released. Two teams of two people worked two experimental plots simultaneously. Each observer made records while walking along a row of 20 plants, spending 2 min on each plant. Each observer walked two different rows in each plantation. Each experimental plot was sampled in two occasions separated by 1 week. The total number of specimens and species recorded in both occasions was used in further analyses.

We identified four main types of land use around the plantations: secondary forest, agricultural land, livestock farms and urban area; however, we concentrated on the proportion of secondary forest. The estimates of secondary forest $1.7 \mathrm{~km}$ from the edge of each plantation were obtained by means of the triangulation technique and estimation tool of Googlearth Pro (2006). We used 
$1.7 \mathrm{~km}$ to cover estimated flight range of stingless bees (Roubik and Aluja 1983; Araújo et al. 2004).

Shannon's diversity indices $(\mathrm{H})$ were obtained from the number of individuals and species (or morphotypes) identified at each site. To determine if bee diversity and abundance were related to the landscape context in which each plantation was established, Spearman's correlation analyses were calculated between the proportion of secondary forest with the calculated $\mathrm{H}$ and number of specimens of the abundant $A$. mellifera, $F$. nigra and Cephalotrigona zexmeniae in each plantation. The significance of the correlations were calculated using a hypothesis test using the Student's $t$ approximation (Zar 1999).

All statistical analyses were conducted using the SAS statistical package 9.2 (SAS Institute 2008).

\section{RESULTS}

\subsection{Breeding system}

There were significant differences amongst treatments in fruit set $\left(F_{5,70}=54.75 ; P<0.001\right)$, fruit weight $\left(F_{5,57}=10.25 ; P<0.001\right)$ and seed weight $\left(F_{5,57}=11.28 ; P<0.001\right)$. In all cases, the effect of tree was not significant, for fruit set $\left(F_{14,70}=1.29 ; P=0.234\right)$, fruit weight $\left(F_{14,57}=1.59\right.$; $P=0.11)$ and seed weight $\left(F_{14,57}=1.66 ; P=0.09\right)$, respectively. The lowest fruit set was obtained for the treatment with permanently bagged flowers and an intermediate level of fruit set was collected for the self-pollination treatment (Table I). Both open and cross-pollinated flowers had similar fruit set values but were significantly higher compared with self-pollinated and permanently bagged flowers. Fruit and seed obtained from permanently bagged flowers had significantly lower weights compared with the other treatments, which were not significantly different amongst them (Table I).

\subsection{Pollinator performance}

\subsubsection{Insect visitors of flowers}

Bees were the dominant insects in the experimental plantation, out of a total of 368 insects recorded a total of 211 were Apoidea (57 \%), followed by Formicidae (83 specimens, $22.5 \%$ ). In the Superfamily Apoidea, the following species were registered = Augochlorella spp. (1 morphotype $=10$ records), Lasioglossum spp. (2 morphotypes $=14$ records), $F$. nigra (135 records) and A. mellifera (52 records). The latter two species were predominant in the plantation, with 36 and $14 \%$ of all insects registered, respectively. Formicidae was represented by two genera, Camponotus (38 records) and a possibly Monomorium species (45 records). Insects other than Apoidea and Formicidae were present in smaller numbers: the wasp Brachygastra mellifica (29 records) and flies of various families (35 records) as well as butterflies and beetles which were much less frequent with 5 records each.

Table I. Mean values and standard errors of fruit set, weight of fruit and seed obtained from J. curcas flowers subject to six pollination treatments.

Variables

\begin{tabular}{lccr}
\cline { 2 - 4 } Treatments & Fruit set (\%) & Fruit weight $(\mathrm{g})$ & Seed weight $(\mathrm{g})$ \\
\hline Bagged (no insect pollination) & $4 \pm .09 \mathrm{a}$ & $7.68 \pm 0.9 \mathrm{a}$ & $2.89 \pm 0.37 \mathrm{a}$ \\
Self-pollination & $54 \pm 0.12 \mathrm{~b}$ & $9.66 \pm 0.28 \mathrm{~b}$ & $3.27 \pm 0.11 \mathrm{~b}$ \\
Cross-pollination & $83 \pm 0.14 \mathrm{c}$ & $9.87 \pm 0.22 \mathrm{~b}$ & $3.49 \pm 0.09 \mathrm{~b}$ \\
Open pollination & $85 \pm 0.13 \mathrm{c}$ & $10 \pm 0.21 \mathrm{~b}$ & $3.51 \pm 0.09 \mathrm{~b}$ \\
F. nigra & $78 \pm 0.14 \mathrm{c}$ & $9.88 \pm 0.21 \mathrm{~b}$ & $3.45 \pm 0.08 \mathrm{~b}$ \\
A. mellifera & $76 \pm 0.14 \mathrm{c}$ & $9.92 \pm 0.22 \mathrm{~b}$ & $3.39 \pm 0.09 \mathrm{~b}$ \\
\hline
\end{tabular}

Different letters in a column indicate significant differences amongst treatments at $(P<0.01)$ 


\subsubsection{Single bee visit experiments for pollination efficiency}

There were no statistical differences in the percentage of fruit set nor the values of fruit and seed weight between $F$. nigra and $A$. mellifera $(P>0.01$; Table I). There were significant differences in the fruit set produced in bee-visited flowers with regards to the self-pollinated and pollinator-excluded flowers (see results in section 3.1), but not so with those produced by cross-pollinated and open-pollinated flowers. Interestingly, fruit and seed produced by selfpollination had similar weight to those obtained by single visits of $A$. mellifera and $F$. nigra (Table I).

\subsubsection{Bee visits to male and female flowers}

Compared to $A$. mellifera, $F$. nigra was significantly more abundant at all times $\left(F_{1,90}=278.76 ; P<0.001\right)$. Time of day affected bee abundance significantly with the the highest abundance of both bee types at 1000 hours $\left(F_{4,90}=36.80 ; P<0.001\right)$ (Figure 1).

The inflorescences in the experimental plantation varied in the number of flowers of each sex. The number of male flowers was always higher but the ratios of male: female flowers in the experimental inflorescences ranged between 14:1 and 46:1. The number of individuals of both bee species correlated positively with the ratio of male to female flowers ( $F$. nigra, $r s=$ 0.858; $P=0.001$ and A. mellifera, $r s=0.708 ; P=$ 0.003 ) (Figure 2).

The preference of male flowers over female ones was corroborated when analyzing the number of visits that bees of each species did to both types of flower. The abundance of $F$. nigra and $A$. mellifera was significantly higher on male than female flowers $(t=-0.75, d f=19$; $P<0.001$ and $t=-0.63, d f=19 ; P<0.001$ respectively; Figure 3).

Nectar quantity did not differ between male $(3.42 \pm 2.91 \mu \mathrm{l})$ and female flowers $(3.05 \pm 1.98 \mu \mathrm{l}$; $t=0.19, d f=19, P=0.851)$ nor did sugar concentration (male: $39.92 \pm 1.98^{\circ}$ Brix and female $40.07 \pm$ $3.07^{\circ}$ Brix $\left.t=0.61, d f=19, P=0.547\right)$.

\subsection{Bee diversity and secondary forest surrounding plantations}

The diversity of bee species/morphotypes in the six plantations ranged between 6 and 14 . Considering the six experimental plantations, 592 bee records were made, the dominant bees being

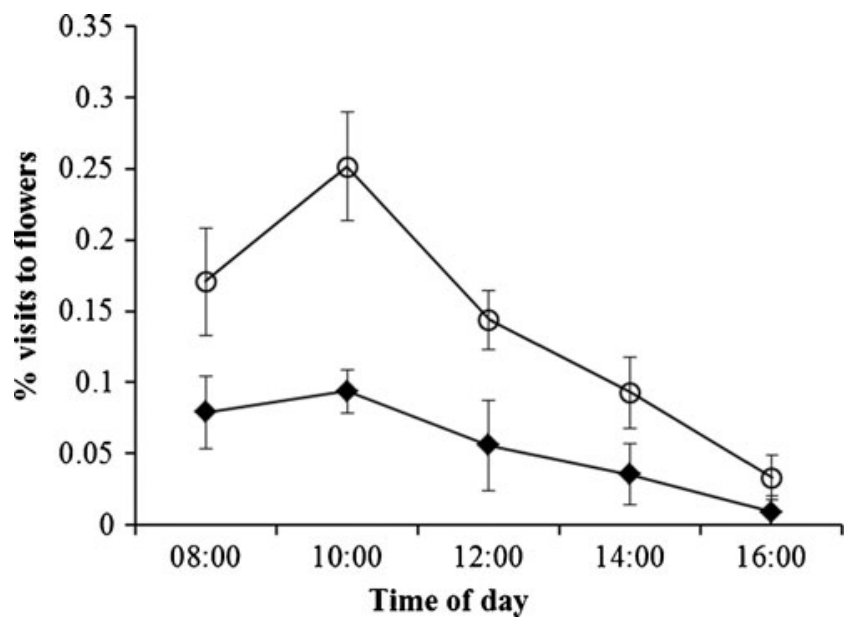

Figure 1. Percentage of visits done by the stingless bee Frieseomelitta nigra (white circles) and the honey bee Apis mellifera (black diamonds) to flowers of Jatropha curcas at different times of day. Means and standard deviations are presented. 


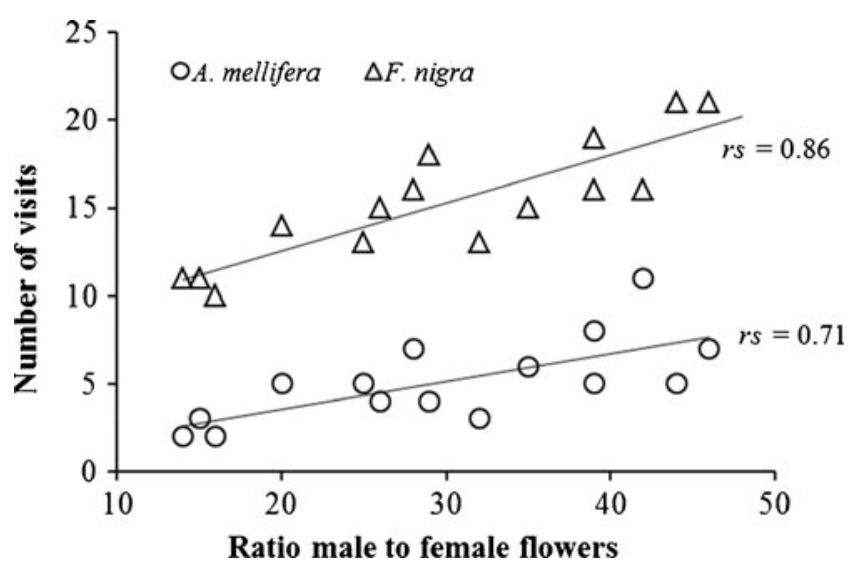

Figure 2. Correlation between the number of visits to flowers of J. curcas by the bees F. nigra and A. mellifera and the ratio of male to female flowers per inflorescence

the highly social stingless bees Cephalotrigona zexmeniae (234 records), F. nigra (195) and the honey bee $A$. mellifera (78); however, the relative frequency of each species varied amongst sites. Two other species of stingless bees were found but in lower numbers Trigona fulviventris (29 records) and Nannotrigona perilampoides (16). Bee species from other taxa were found in lesser numbers, amongst them Halictids of the genera Augochlorella (2 morphotypes with 10 and 4 records each), Augochlora (3 morphotypes with 4, 7 and 8 records), Lasioglossum (4 morphotypes with 2, 2, 4 and 7 records), and 1 species of Xylocopa (2 records).

There was a positive and significant correlation between Shannon index and the proportion of forest around the plantations at $1.7 \mathrm{~km} r s=0.93$; $P<0.001$ (Figure 4). The correlations between abundance and the proportion of forest were positive and significant for the dominant species of stingless bees (F. nigra $r s=0.74 ; P=0.019$ and $C$. zexmeniae $r s=0.92 ; P=0.004)$. In contrast, there was no significant correlation in the case of the honey bee $(r s=-0.27 ; P=0.483)$.

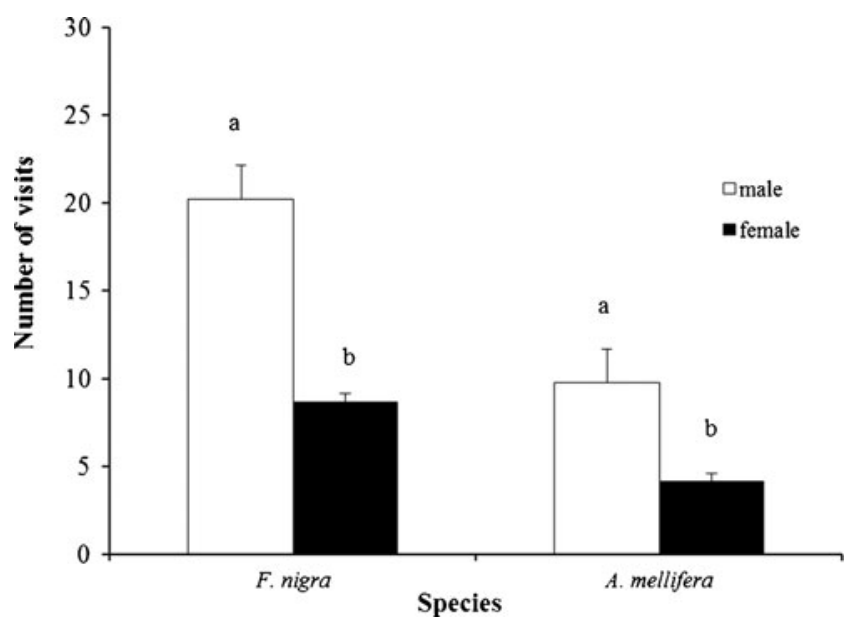

Figure 3. Comparison of the number of visits to J. curcas male and female flowers by F. nigra and A. mellifera 


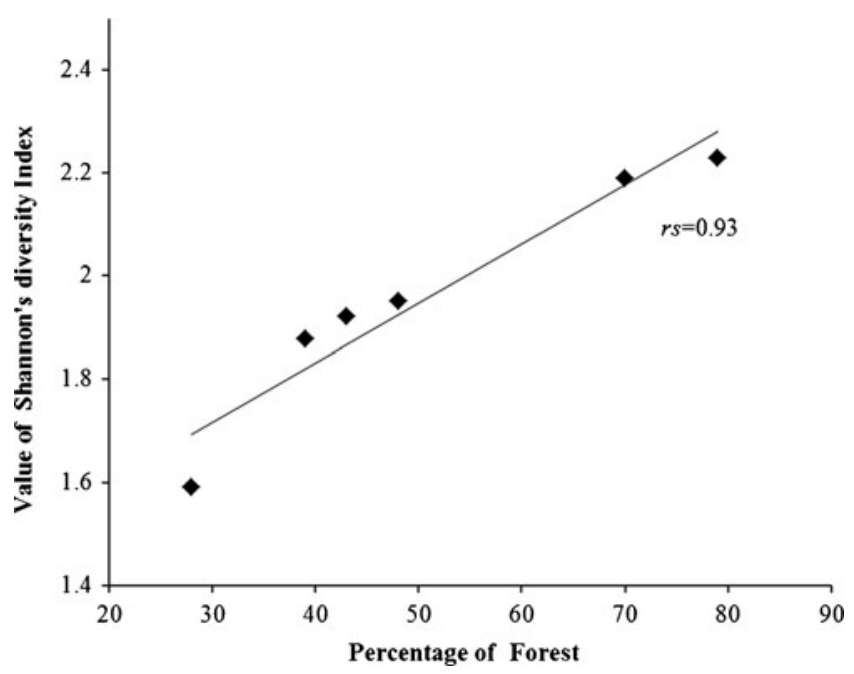

Figure 4. Correlation between Shannon's $H$ index of bee diversity at six $J$. curcas plantations and the percentage of secondary forest in the matrix surrounding them

\section{DISCUSSION}

Our results give evidence on the importance of cross-pollination for high fruit set in commercial $J$. curcas plantations and that bees seem the most important pollinators due to their abundance and high efficiency regarding fruit set and quality. Moreover, we found a relationship between the landscape matrix surrounding commercial plantations with the diversity and abundance of bees in them.

Evaluating the breeding system in $J$. curcas confirmed that fruit and seed production could result from both self- and cross-pollination (Abdelgadir et al. 2012). Nevertheless, higher levels of fruit set resulted only from crosspollinated flowers indicating that pollinators that can carry pollen across plants are essential in commercial plantations. Fruit was also obtained from flowers that remain bagged across the experiment, but set was very low indicating that pollen could not access through bagged flowers or that it may not be effectively dispersed by wind as suggested by Chang-Wei et al. (2007). It has also been suggested that a percentage of fruit could be the result of apomixis (Kaur et al. 2011), although this possibility cannot be excluded from our results, we recorded lower percentages compared to rates reported elsewhere (Chang-Wei et al. 2007). Although under natural conditions the transference of pollen amongst inflorescences on the same plant could be feasible, self-pollinated flowers resulted in lower fruit set compared with cross-pollinated ones. It has been argued that cross-pollination is important given a time gap between anthesis of male and female flowers within an inflorescence (Solomon Raju and Ezradanam 2002; Luo et al. 2011). Thus, although $J$. curcas is self-compatible, pollinators moving across plants are essential for increasing productivity and, thus, for sustainable harvests for biofuel production (Bhattacharya et al. 2005; Chang-Wei et al. 2007; Kaur et al. 2011).

We found that bees were the most frequent insect visitors of $J$. curcas in Mexico. Studies in other latitudes report bees as the most important taxon for cross-pollination of J. curcas due to their large presence on the plantations as we also found, and their potential high mobility (Bhattacharya et al. 2005; Chang-Wei et al. 2007). However, our study is the first to compare the individual pollination performance of bees visiting J. curcas. The most frequent species in our study site were the stingless bee $F$. nigra and the honey bee. Both bee species were highly abundant in the morning and decreased after midday which seems to 
coincide with the peak of nectar secretion of $J$. curcas (Luo et al. 2011).

Although both bees were effective pollinators, their abundance differed significantly. Stingless bees were present in larger numbers compared to A. mellifera, contrasting with studies elsewhere (Bhattacharya et al. 2005; Abdelgadir et al. 2009). This result could have important implications because pollinator effectiveness depends on the combined effects of individual efficiency and abundance (Herrera 1987; Fumero-Cabán and Meléndez-Ackerman 2007). In our study, stingless bees with a larger population could pollinate more flowers per time unit compared with $A$. mellifera. It is not clear why honey bees were not abundant on the crop, as the calculated number of feral and managed colonies in the Yucatan Peninsula is above $17 / \mathrm{km}^{2}$ (Quezada-Euán 2000). Thus, studies on the factors affecting the abundance of both bee types and comparative rates of pollen deposition/tube development are needed for a better indication of their pollination performance.

We found that the number of male flowers was correlated with the numbers of bees of both species and that male flowers were more attractive than female ones (Solomon Raju and Ezradanam 2002), even though in our plantation flowers of both sexes produced similar amounts of nectar and sugar. Differences in the relative attraction of $J$. curcas male and female flowers to bees could be related to pollen offer, but we did not analyze the relative abundance of pollen and nectars gatherers to support this suggestion. Selection and breeding of $J$. curcas aims at increasing the ratio of female flowers per inflorescence, as this should in theory increase fruit production per plant (Sakamoto and Matsuoka 2004; King et al. 2009). However, it is important to consider our results because selection for more female flowers could lead to a reduction in the proportion of male ones and this may affect insect visits. Our study covers only a part of the day when insects were most active, therefore evaluating differences in nectar production throughout the day, pollen depletion of male flowers and (consequently) in visitation rates to male or female flowers is important.
The last part of our study gives some additional cues to management practices that may improve the opportunities for sustainable pollination of $J$. curcas plantations. The diversity and abundance of native bees showed a positive correlation with the proportion of forest surrounding the crops. However, in the case of the honey bee, no correlation was evident. These results could be a consequence of their populations being potentially less affected by the natural variation of blossoms or nesting sites given the management provided by beekeepers. In contrast, meliponine populations seem strongly depending on forest habitats as providers of nesting sites and food (Brown and Albrecht 2001; Ricketts 2004; Brosi et al. 2007; Brosi 2009; Klein 2009). This is important as the lack of nesting sites around crops can reduce bee diversity and flower-visiting frequency (Ricketts et al. 2008). Such a local variation in nests could for instance explain the absence $C$. zexmeniae in our experimental plantation. Thus, evaluations of species abundance and their effect on $J$. curcas pollination at a larger scale are needed.

Presently, the artificial reproduction of stingless bee colonies is limited which prevents increasing their numbers for commercial pollination purposes (Cauich et al. 2004; QuezadaEuán 2005). Thus, the best sustainable practice to increase the numbers of native bees on $J$. curcas flowers would be the preservation of secondary forest areas around the crops where those bees could nest and find food, in order to increase their presence during the blossom time.

\section{ACKNOWLEDGMENTS}

We thank the Biofuel Company from Yucatan that allowed us to conduct this study. The study was supported by projects Foncicyt- EU "MUTUAL" and Sep-Conacyt 103341 "Conservación de las abejas sin aguijón de México". We thank Jesica Pérez, Humberto Moo-Valle, Gretel Castillo, Liliana Guerrero, Guillermo Cauich and Aristeo Caro for help during field work. We are most thankful to three anonymous reviewers for their valuable input on our ms.

Pollinisateurs des systèmes agricoles produisant du biocarburant: la diversité et la performance des 
abeilles (Hymenoptera: Apoidea) sur Jatropha curcas au Mexique

\author{
Biocarburant / Jatropha/noix / abeille sans aiguillon / \\ pollinisation / paysage
}

Bestäuber in Biotreibstoff produzierenden landwirtschaftlichen Systemen: Diversität und Bestäubungsleistung von Bienen (Hymenoptera: Apoidea) auf Jatropha curcas in Mexico

Biodiesel / Jatropha / stachellose Biene / Bestäubung / Purgiernuss / Landschaft

\section{REFERENCES}

Abdelgadir, H.A., Johnson, S.D., Van Staden, J. (2009) Pollinator effectiveness, breeding system and tests for inbreeding depression in the biofuel seed crop, Jatropha curcas. J. Hortic. Sci. Biotechnol. 84, 319-324

Abdelgadir, H.A., Johnson, S.D., Van Staden, J. (2012) Pollen viability, pollen germination and pollen tube growth in the biofuel seed crop Jatropha curcas (Euphorbiaceae). South Afr. J. Bot. 79, 132-139

Abhilash, P.C., Srivastava, P., Jamil, S., Singh, N. (2011) Revisited Jatropha curcas as an oil plant of multiple benefits: critical research needs and prospects for the future. Environ. Sci. Poll. Res. 18, 127-131

Achten, W.M.J., Nielsen, L.R., Aerts, R., Lengkeek, A.G., Kjae, R.E.D., Trabucco, A., Hansen, J.K., Maes, W.H., Graudal, L., Akinnifesi, F.K., Muys, B. (2010) Towards domestication of Jatropha curcas. Biofuels 1, 91-107

Araújo, E.D., Costa, M., Chaud-Netto, J., Fowler, H.G. (2004) Body size and flight distance in stingless bees (Hymenoptera: Meliponini): inference of flight range and possible ecological implications. Braz. J. Biol. 64, 563-568

Atmowidi, T., Riyanti, P., Sutrisna, A. (2008) Pollination effectiveness of Apis cerana Fabricus and Apis mellifera Linnaeus (Hymenoptera: Apidae) in Jatropha curcas L. (Euphorbiaceae). Biotropia 15, 129-134

Bhattacharya, K., Datta, S., Datta, K. (2005) Floral biology, floral resource constraints and pollination limitation in Jatropha curcas L. Pakistan J. Biol. Sci. 8, 456-460

Brosi, B.J. (2009) The complex responses of social stingless bees (Apidae: Meliponini) to tropical deforestation. For. Ecol. Manag. 258, 1830-1837

Brosi, B.J., Daily, G.C., Ehrlich, P.R. (2007) Bee community shifts with landscape context in a tropical countryside. Ecol. Appl. 17, 418-430

Brown, J.C., Albrecht, C. (2001) The effect of tropical deforestation on stingless bees of the genus Melipona (Insecta: Hymenoptera: Apidae: Meliponini) in central Rondonia. Braz. J. Biogeogr. 28, 623-634
Caudwell, R.W., Hunt, D., Reid, A., Mensah, B.A., Chinchilla, C. (2003) Insect pollination of oil palm - a comparison of the long term viability and sustainability of Elaeidobious kamerunicus in Papua New Guinea, Indonesia, Costa Rica, and Ghana. ASD Oil Palm Papers 25, 1-16, http:// www.asd-cr.com/paginas/english/articulos/bol251en.html.

Cauich, O., Quezada-Euán, J.J.G., Macias-Macias, J.O., Reyes-Oregel, V., Medina-Peralta, S., Parra-Tabla, V. (2004) Behavior and pollination efficiency of Nannotrigona perilampoides (Hymenoptera: Meliponini) on greenhouse tomatoes (Lycopersicon esculentum) in subtropical Mexico. J. Econ. Entomol. 97, 475-481

Chang-Wei, L., Kun, L., You, C., Yong-Yu, S. (2007) Floral display and breeding system of Jatropha curcas L. For. Stud China 9, 114-119

Dafni, A., Kevan, P.G., Husband, B.C. (2005) Practical pollination biology. Enviroquest Ltd., Cambridge

Fairless, D. (2007) The little shrub that could - maybe. Nature 449, 652-655A

Fargione, J.E., Plevin, R.J., Hill, J.D. (2010) The ecological impact of biofuels. Annu. Rev. Ecol. Evol. Syst. 41, 351-377

Fitzherbert, E.B., Struebig, M.J., Morel, A., Danielsen, F., Brühl, C.A., Donald, P.F., Phalan, B. (2008) How will oil palm expansion affect biodiversity? Trends. Ecol. Evol. 23, 538-545

Foley, J.A., Ramankutty, N., Brauman, K.A., Cassidy, E.S., Gerber, J.S., et al. (2011) Solutions for a cultivated planet. Nature 478, 337-342

Free, J.B. (1993) Insect Pollination of Crops, 2nd edn. Academic, London

Freitas, B.M., Paxton, R.J. (1998) A comparison of two pollinators: the introduced honey bee Apis mellifera and an indigenous bee Centris tarsata on cashew Anacardium occidentale in its native range of $\mathrm{NE}$ Brazil. J. Appl. Ecol. 35, 109-121

Fumero-Cabán, J.J., Meléndez-Ackerman, E. (2007) Relative pollination effectiveness of floral visitors of Pitcairnia angustifolia (Bromeliaceae). Am. J. Bot. 94, 419-424

Herrera, C.M. (1987) Components of pollinator "quality": comparative analysis of a diverse insect assemblage. Oikos 50, 79-90

Hoehn, P., Tscharntke, T., Tylianakis, J.M., SteffanDewenter, I. (2008) Functionalgroup diversity of bee pollinators increases crop yield. Proc. R. Soc. Lond. B. 275, 2283-2291

Jauker, F., Bondarenko, B., Becker, H.C., SteffanDewenter, I. (2012) Pollination efficiency of wild bees and hoverflies provided to oilseed rape. Agric. For. Entomol. 14, 81-87

Kaur, K., Dhillon, G.P.S., Gill, R.I.S. (2011) Floral biology and breeding system of Jatropha curcas in north-western India. J. Trop. For. Sci. 23, 4-9 
King, A.J., He, W., Cuevas, J.A., Freudenberger, M., Ramiaramanana, D., Graham, I.A. (2009) Potential of Jatropha curcas as a source of renewable oil and animal feed. J. Exp. Bot. 60, 2897-2905

Klein, M.A. (2009) Nearby rainforest promotes coffee pollination by increasing spatio-temporal stability in bee species richness. For. Ecol. Manag. 258, 1838-1845

Kremen, C., Williams, N.M., Aizen, M.A., GemmillHerren, B., LeBuhn, G., et al. (2007) Pollination and other ecosystem services produced by mobile organisms: a conceptual framework for the effects of landuse change. Ecol. Lett. 10, 299-314

Luo, C.W., Huang, Z.Y., Chen, X.M., Li, K., Chen, Y., Sun, Y.Y. (2011) Contribution of diurnal and nocturnal insects to the pollination of Jatropha curcas (Euphorbiaceae) in Southwestern China. J. Econ. Entom. 104, 149-154

Ne'eman, G., Jürgens, A., Newstrom-Lloyd, L., Potts, S.G., Dafni, A. (2010) A framework for comparing pollinator performance: effectiveness and efficiency. Biol. Rev. 85, 435-451

Pranesh, K.J., Gururaja Rao, M.R., Sowmya, H.C., Gowda, B., Savithramma, D.L., Naveen, N.L. (2010) Studies on floral display and mode of reproduction in jatropha (Jatropha curcas L.). Electr. J. Plant Breed. 1, 832-838

Quezada-Euán, J.J.G. (2000) Hybridization between European and Africanized honeybees in tropical Yucatan, Mexico. II. Morphometric, allozymic and mitochondrial DNA variability in feral colonies. Apidologie 31, 443-453
Quezada-Euán, J.J.G. (2005) Biología y uso de las abejas nativas sin aguijón de la península de Yucatán, México (Hymenoptera: Meliponini). Universidad Autónoma de Yucatán, Mérida

Ricketts, T.H. (2004) Tropical forest fragments enhance pollinator activity in nearby coffee crops. Conserv. Biol. 18, 1262-1271

Ricketts, T.H., Regetz, J., Steffan-Dewenter, I., Cunningham, S.A., Kremen, C., et al. (2008) Landscape effects on crop pollination services: are there general patterns? Ecol. Lett. 11, 499-515

Roubik, D.W., Aluja, M. (1983) Flight ranges of Melipona and Trigona in tropical forest. J. Kans. Entomol. Soc. 56, 217-222

Sakamoto, T., Matsuoka, M. (2004) Generating highyielding varieties by genetic manipulation of plant architecture. Curr. Opinion Biotech. 15, 144-147

SAS Institute. (2008) SAS/STAT ${ }^{\circledR} 9.2$ User's Guide. Cary, NC

Solomon Raju, A.J., Ezradanam, V. (2002) Pollination ecology and fruiting behavior in a monoecious species, Jatropha curcas L. (Euphorbiaceae). Curr. Sci 83, 1395-1398

Ye, M., Li, C., Francis, G., Makkar, H.P.S. (2009) Current situation and prospects of Jatropha curcas as a multipurpose tree in China. Agrofor. Syst. 76, 487-497

Zar, J.H. (1999) Biostatistical analysis, 4th edn. Prentice Hall, Englewood Cliffs 